\title{
An Introduction: Foundational Issues in Semantics and Pragmatics
}

\section{Tadeusz Ciecierski ${ }^{1} \cdot$ Paweł Grabarczyk ${ }^{2}$}

Received: 7 September 2020 / Accepted: 12 October 2020/Published online: 27 October 2020

(C) The Author(s) 2020

\begin{abstract}
This introduction to the special issue 'Foundational issues in semantics and pragmatics' contains a brief description of the content of the volume.
\end{abstract}

Keywords Semantics · Pragmatics · Philosophy of Language · Philosophy of Linguistics

The current special issue of Axiomathes is intended to address variety of foundational issues in semantics and pragmatics. The idea of the special issue has its origins at the second Context, Cognition and Communication conference held at the University of Warsaw in June 2018. After the conference we have decided to invite the conference participants to submit their papers for the special issue, we have also announced the open call for papers that attracted a large number of submissions. The special issue contains the best papers that successfully passed the review process.

The topic of the special issue was originally intended to be broad enough to cover numerous themes that are discussed in the fields of philosophy of language, philosophy of linguistics and philosophical logic. The main idea was to account for the proliferation of theories and methods of dealing with language by looking back at some of the common foundational problems of the discipline. We believe that the content of the volume reflects the initial idea very well. The issue starts with the paper by Andrei Moldovan in which the authors defend the thesis that tests for ambiguity do actually work for homonymy (e.g. "bank") and irregular polysemy

Tadeusz Ciecierski

taci@uw.edu.pl

Paweł Grabarczyk

pawg@itu.dk

1 Department of Philosophy, University of Warsaw, Uniwersytet Warszawski, ul. Krakowskie Przedmieści3 3, 00-927 Warsaw, Poland

2 IT University of Copenhagen \& Institute of Philosophy, University of Lodz, Rued Langgaards Vej 7 DK-2300 Copenhagen S Denmark Building: 4F16-4T86, Lodz, Poland 
(e.g. "button", "cold") but have limited application in the case of regular polysemy (e.g. "bowl" as container and as unit of food). The author applies his analysis to the discussion over the issue of the alleged ambiguity of definite descriptions. In the next paper of the volume Jose Manuel Viejo sketches an original indexical theory of belief attributions. Its main idea is to take that-clauses of attitude reports to refer to contextually salient representation-propositional content pairs ('interpreted representations'). Pelle Leth in Utterance Interpretation and Actual Intentions argues that in the process of communication the actual communicative intentions of the speaker are irrelevant as the hearer is interested at most in what the speaker present as her intention as well as in the interpretation of the utterance that is acceptable for the speaker. The topic of utterance interpretation is also addressed in Joanna OdrowązSypniewska's paper. She argues that during the interpretation process interpreters construct literal propositional units, which are not truth-evaluable but which play an important role in the process of utterance interpretation (she discusses the relation of her view to theories of Simons and Recanati). In the next paper of the issue Justina Berskyte provides a detailed criticism of the idea of indexical contextualism as a semantic theory of predicates of personal taste (predicates like "tasty" or "cute"), that is the theory that claims that semantic content of such predicates varies across contexts in virtue of implicit indexical element they contain. She discusses two major variants of indexical contextualism and shows that neither is capable of the adequate description of the behavior of the predicates in question. Richmond Kwesi discusses in his paper a non-cognitivist account of metaphors according to which metaphors are not truth-evaluable because of the special phenomenological character connected with the grasping of metaphorical content. Kwesi criticizes this view and argues that the perceptual account of metaphor is consistent with being the subject of the truth-conditional assessment. In Now, Imagine an Actually Existent Unicorn... On Russellian Worries for Modal Meinongianism Andreas Pieter de Jong takes up a defense of characterization principle of Modal Meinongianismaccording to which any condition whatsoever is satisfied by some object in some world-against the criticism of Everett. Joanna Klimczyk in Compositional Semantics and Normative 'Ought' argues that the semantics for normative terms in general (and 'ought' in particular) transcends the resources of lexical semantics and the principle of compositionality and sketches an alternative semantic account she calls 'substantive semantics'. In the next article of the issue Filip Kawczyński discusses the idea of metametasemntics and defends it against the recent criticism by Ori Simchen. He argues that metametasemantics not only does not pose any danger to metasemantics but also that it provides a solid ground for developing a semantic theory that benefits from both speaker's and audience's metasemantics. In The Content and Logic of Imperatives Nicolas Fillion and Matthew James Lynn defend the idea of imperative inference and presents a version of this idea that assumes that if the contents of the imperative premises have directive force, then the content of the imperative conclusion has directive force. In the last paper of the volume Robert van Rooij and Katrin Schulz develop a general account of the appropriateness of conditionals in terms of evidential support.

As it can be seen from the brief description given above the special issue should be of some interests to philosophers, logicians and linguists who are work on 
ambiguity, the concept of semantic value, context dependence, utterance interpretation, the semantics of fictional discourse and metaphoric utterances, deontic logic, the semantic and pragmatics of conditionals and imperatives.

The completion of the present volume would not be possible without the patience of the authors, the work of the reviewers and the help of the editor in chief of Axiomathes. We would like to express our gratitude to all these people.

Open Access This article is licensed under a Creative Commons Attribution 4.0 International License, which permits use, sharing, adaptation, distribution and reproduction in any medium or format, as long as you give appropriate credit to the original author(s) and the source, provide a link to the Creative Commons licence, and indicate if changes were made. The images or other third party material in this article are included in the article's Creative Commons licence, unless indicated otherwise in a credit line to the material. If material is not included in the article's Creative Commons licence and your intended use is not permitted by statutory regulation or exceeds the permitted use, you will need to obtain permission directly from the copyright holder. To view a copy of this licence, visit http:// creativecommons.org/licenses/by/4.0/.

Publisher's Note Springer Nature remains neutral with regard to jurisdictional claims in published maps and institutional affiliations. 